\title{
Buddha Air: The Ace Airline of Nepal
}

\section{Dr. Sushil Kumar Pant ${ }^{1}$}

${ }^{1}$ Corresponding

email:suspant@gmail.com

Received date: May 10, 2021

Revised date: November 13, 2021

Accepted date: Dec 10, 2021

\section{Cite this paper}

Panta, S.K. (2021). Buddha Air: The Ace Airline of Nepal. International Research Journal of Management Science, vol.6(1), pp. 105-109

\begin{abstract}
This is a case study of a pioneering airlines company in the Nepalese aviation sector. The airlines came into full operation in 1997 by flying a brand new Beachcraft-1900D for a regular sightseeing to Mount Everest. When the airlines entered the field which was opened for the private sector by the government of Nepal in the early nineties, the country's nascent aviation sector was in a state of take-off attracting a growing number of airline companies. Despite tough competition, the company expanded its fleet from a single aircraft to seven in number in 10 years of its operation. In 2008, the company purchased two ATR-42 aircrafts under the financial assistance of the International Finance Corporations (IFC/World Bank) and added a 70-seat ATR 72-212 in June 2010. With a range of aircrafts in its fleet, Buddha Air has today spread its wings to 13 destinations, including two international ( 1 seasonal and 1 charter flight) and 11 domestic destinations.
\end{abstract}

After more than two decades of its service to the country's civil aviation and tourism sector, Buddha Air was recognized as "the most successful airlines" for its sustained growth as well as for the safety and satisfaction of its customers. However, it had tackled with the price war in the face of higher cost of operations as a result of the increased number of airlines in this sector. Recalling the difficult situation due to the indiscriminate price competition, the Managing Director of the airlines, said that the pricing strategy was challenging and there was a strong urge for an unfair price competition from the rivals. "The low cost strategy as pursued by our competitors was not appropriate for our company as we had relatively higher cost of operation as we owned bigger aircrafts," he said. While the price war remained a major hurdle in its operation, an attempt to venture into international flights was another challenge it encountered for the sustained growth of the airlines.

Keywords: Dividend policy, Stock price volatility, dividend yield, dividend announcement, dividend payout 


\section{Company background}

Buddha Air was formally established on 23 April 1996 as a private limited company by Surendra Bahadur Basnet, a retired Supreme Court judge and a former minister, and his son Birendra Bahadur Basnet. Initiated with a single aircraft for sightseeing mountain flights, it had seven aircrafts to its fleet in ten years spreading services to many destinations. As of today, Buddha Air has one of the largest fleet of aircrafts giving it a competitive advantage. The airlines also offered air charter flights and mountain sightseeing flights daily. With its flight services to Paro as the first international flight since 2010, Buddha Air became the first foreign airline company to start flights to Bhutan.

\section{Operations}

The airline is the first private company to build its own hangar for maintenance of its fleet of aircrafts. For the first time in the country's aviation history, the IFC (a subsidiary of the World Bank) provided loan to this company to purchase aircrafts and build its own hangar. The hangar was awarded IPMA Award in big and medium sized projects in 2014. It also provided maintenance services to Druk Air of Bhutan and Novo Air of Bangladesh. The airlines states that 60 percent of its employees work from the hangar to coordinate smooth maintenance and operations of its flights.

They also maintained a large storage of spare parts to ensure uninterrupted flight services to their customers. For that reason, the company maintained the stock of parts equivalent to around US $\$ 12.5$ million. Also it had total of 155 technical staff included engineers and other technical staff for the maintenance of their aircrafts without any interruption.

Buddha Air gave utmost priority to the safety of their passengers as it followed the safety measures at par with international standard. In order to ensure this, it conducted two yearly International Operational Safety Audit which is based on IATA standards and had 19 safety audit staff trained by this organization. Further, all their flights were monitored through Flight Data Monitoring System so that no untoward incidents would occurr before or during the flights. This practice, as the airlines claimed, was conducted only by Buddha Air in Nepal.To give continuity to this standard, it had ensured regular training and development programs for its crew members, engineers and technical staff so that they always remained updated and ready to take any challenges with regard to operation of the aircrafts.

\section{Finance}

The company is considered as one of the most financially transparent companies in Nepal. Its financial statements were easily accessible for the concerned authorities despite the company being privately owned. The airlines had been recognized by the Inland Revenue Department as the highest tax paying company in the tourism sector. Since its inception, the company had paid Rs.3.28 billion as tax to the government, indicating it as a good corporate citizen of the nation.

The company was in profits for the last fifteen years. In 2015-16, it earned Rs.200 million as profit before tax in a turnover of Rs. 5 billion. Despite the net profits, it borrowed Rs. 750 million from local banks to add two ATR 72_500 series to its fleet. Nevertheless, the company's finance director asserted that Buddha Air will be completely free from loan in less than two years. 


\section{Marketing}

Buddha Air had a marketing team with experienced personnel in travel and tourism business. Apart from a good networking with travel and tour operators for the marketing of services, the airlines had diversified its promotion through mass media and digital marketing using Facebook page, Twitter and Instagram.

During its 20 Years of Services of advertising campaign, the company provided a human-feel by promoting the contribution of their crew members, engineers and other staff to provide the best services to the customers. It indicted the consolidated efforts of the company family assuring its image as the country's leading airlines in terms of safety and services.

The pricing strategy of the company was essentially not based on the price leadership. It believed in adopting differentiation strategy for pricing with a premium for reliable and safe flights to its customers. However, it followed three tiers of prices for attracting customers. They were categorized as normal fare, reduced fare and discounted fare which were based on seasons and booking from the passengers.

Buddha Air also had a club membership provision under the banner called "Royal Club" for those passengers who flew frequently with it. The membership was open for every passenger in which each flight was given certain points and a passenger would receive a free ticket to one destination based on the accumulated points. So far, there are 8,225 Platinum members and 119,820 Gold Card members registered with the company. The company considered it as a marketing strategy to maintain a long term relationship with customers and also the key to success in today's highly competitive market. As a result, Buddha Air had been able to share 60 percent of the market covered by the destinations where its flights services are available.

\section{Human resources}

Currently, Buddha Air employs about 800 people. The company's recruitment system is traditional as it gives preference to those candidates who are referred by current employees. "Although this system had some limitations, we experienced effective outcomes from it," according to the company's Human Resource Manager. He gave credit to the company's old and loyal employees for this.

In terms of remuneration and incentives, the company is one of the best employers in the country's aviation industry. The Managing Director of the company claimed that the salary of employees was increased by around 20 to 30 percent in every two years. Besides, the airline also provided uniforms, food, conveyance, insurance, gratuity, provident fund and bonus for its employees as motivation. "The labor union at the company was virtually dysfunctional just because we treated our employees as family members so that we had never faced serious problems related to human resources in the two decades of our operations", he said.

The company had invested a huge amount in training of its employees. Although most of the investment has been absorbed by the training of crew members and technical staff, a reasonable amount of money was allocated for training of other staffs. According to the company profile, Buddha Air had invested 
approximately Rs. 80 million in training for crew members; Rs.30 million for technical training, Rs.6 million for non-flying training and Rs.4 million in other training and seminars in 2016/17.

\section{State of the airline industry in Nepal}

The history of airline services in Nepal began with the Indian and other foreign airlines flying into the country in the early 1950s. However, the history of aviation industry in Nepal began with the establishment of the Royal Nepal Airlines Corporation (RNAC) in July 1, 1958 which initially served only domestic destinations. Air services during that time was very important as the country had limited road connections. The airlines began its international flight by operating Fokker planes in its fleet in 1966. It was the only national flag carrier and the only airlines until the political changes of 1990.

With the liberal economic policy in effect in the early 1990s, the country's civil aviation sector, for the first time, was allowed for the private sector in Nepal. Following that the private sector airlines grew in number with the establishment of Nepal Airways, Nepal Air Chartered Limited (later converted into Everest Air), and Necon Air flying in various domestic sectors. This helped to meet the demand in addition to the services provided by RNAC. As the number of airline companies increased, there was an increased competition in the civil aviation sector which assured better services at the competitive prices. However, Nepal Airways and Everest Air, which were the pioneer private airlines, discontinued operating after few years, making Necon Air as the only private airlines in the field for a couple of years. Although, it was also the first private airlines to begin international flight by flying to India, it also stopped its services later on. But there was a series of new entrants in this sector counting the total number to 14. Chief among them were Buddha Air, Shree Airlines, Yeti Airlines, Tara Airlines, Cosmic Air, and Necon Air.

Yeti Airlines and its sister company Tara Airlines were the largest airline companies in the country since they operated in both trunk and STOL destinations of Nepal. Emerged as a competitor for a long time, Yeti Airlines is also a stakeholder of the Himalayan Airlines which is the only private airlines which operates for international flights from Nepal. As a foreign joint venture company, Yeti Airlines gets more passengers on-transit between Tribhuvan International Airport in Kathmandu and other airports all over the country.

Regarding the competitive situation in this sector, there is a big rivalry between Buddha Air and Yeti Airlines as both airlines operate for the same destinations and mountain sightseeing flights. Relatively very new entrant, Shree Airlines emerged as a direct competitor to both Buddha Air and Yet Airlines since 1999. Established as the largest helicopter operator with a brand image, Shree Airlines had an advantage in the fixed wing industry than other airlines. With its helicopter services, it has an added advantage for taking passengers to remote destinations.

\section{Price competition and international flights}

In general, the airline industry compete on the basis of price. As a result, there is a possibility of price war as a business strategy among airline operators. But this is considered as a risky strategy as the airlines operate at very low profit-margins all over the world. In the contrary, Nepalese airlines were 
often deemed to be profit-making companies. Yet, the increasing trend in price competition would have negative impact in the long run.

This was more visible in the Nepalese airline industry few years ago when, Cosmic Air launched an aggressive pricing strategy which offered very low prices to its passengers and also introduced a costly sales promotion activity in every flight. Later, Necon Air also followed the same strategy forcing others to follow the practice. Given the situation, Buddha Air had tough times avoiding the price war as it had relatively higher cost of operations than its rival companies. This is because the company owned 19-seater Beechcraft airplanes seeking higher cost of operations. Referring to the situation, the managing director of the company, said that those were the difficult days of making the right choice of business strategy. $\mathrm{He}$ added that despite the strong urge and need to enter into price competition that time the airlines had to avoid it due to the risk of it becoming unsustainable. However, the company faced very difficult time attracting passengers as other companies followed the low-cost pricing strategy which forced some companies to close down their business. "But Buddha Air tackled the situation making a right decision," he asserted.

In addition to the price competition, Buddha Air faced a hard time in venturing international flights as well. As a first set-back, its attempt to launch Pokhara-Lucknow (India) flight failed before introducing it. Similarly, it could not continue charter flights between Kathmandu and Benaras (India) regularly. Including Buddha Air, its competitors also failed in this venture, reflecting inability of Nepali airlines' in operating international flights. Nevertheless, Himalayan Airlines - a joint venture between Nepali and Chinese investors - is the only company which had successfully been operating international flights from the country since the last two years, indicating business scopes in this sector.

\section{Future Outlook}

The airline industry in Nepal indicates promising signs due to growing prospects in the country's tourism sector. This gives opportunities for Nepalese airline companies to expand its business and attracting more investment in this sector. Along with this, the competition in pricing and customer services indicated more challenges. While this seems inevitable, the airline companies in Nepal will face difficult times for venturing international flights without a collaborative move to cash-in-on the growing prospects in the international air travel market. As a first-mover, Buddha Air has a plan to launch international flights from Pokhara, second important tourist destination in Nepal, once the international airport comes into operation. Yet, it depends on the company's strategy and the business environment in the country as well as globally. 